\title{
Differential basal expression of immune genes confers Crassostrea gigas resistance to Pacific oyster mortality syndrome
}

\author{
Julien de Lorgeril ${ }^{1}$, Bruno Petton ${ }^{2}$, Aude Lucasson ${ }^{1}$, Valérie Perez ${ }^{1}$, Pierre-Louis Stenger ${ }^{1,3}$, Lionel Dégremont ${ }^{4}$, \\ Caroline Montagnani ${ }^{1}$, Jean-Michel Escoubas ${ }^{1}$, Philippe Haffner ${ }^{1}$, Jean-François Allienne ${ }^{1}$, Marc Leroy', \\ Franck Lagarde ${ }^{5}$, Jérémie Vidal-Dupiol ${ }^{1}$, Yannick Gueguen ${ }^{1}$ and Guillaume Mitta ${ }^{1 *}$ (D)
}

\begin{abstract}
Background: As a major threat to the oyster industry, Pacific Oyster Mortality Syndrome (POMS) is a polymicrobial disease affecting the main oyster species farmed across the world. POMS affects oyster juveniles and became panzootic this last decade, but POMS resistance in some oyster genotypes has emerged. While we know some genetic loci associated with resistance, the underlying mechanisms remained uncharacterized. So, we developed a comparative transcriptomic approach using basal gene expression profiles between different oyster biparental families with contrasted phenotypes when confronted to POMS (resistant or susceptible).

Results: We showed that POMS resistant oysters show differential expression of genes involved in stress responses, protein modifications, maintenance of DNA integrity and repair, and immune and antiviral pathways. We found similarities and clear differences among different molecular pathways in the different resistant families. These results suggest that the resistance process is polygenic and partially varies according to the oyster genotype.

Conclusions: We found differences in basal expression levels of genes related to TLR-NFKB, JAK-STAT and STINGRLR pathways. These differences could explain the best antiviral response, as well as the robustness of resistant oysters when confronted to POMS. As some of these genes represent valuable candidates for selective breeding, we propose future studies should further examine their function.
\end{abstract}

Keywords: Pacific oyster, Oyster disease, Resistance, OsHV-1, Antiviral molecular pathways, Invertebrate immunity

\section{Background}

Originally from Asia, the Pacific oyster (Crassostrea gigas) has been introduced to numerous countries throughout the world (Canada, USA, Australia, NewZealand, Chile, Mexico, Argentina, Brazil, South Africa, Namibia and in numerous European countries including France) during the twentieth century and has become the main oyster species farmed worldwide [1]. For decades, C. gigas has suffered from mortalities, but the severity of these outbreaks has dramatically increased since 2008. These outbreaks mainly affect juvenile

\footnotetext{
* Correspondence: mitta@univ-perp.fr

${ }^{1}$ IHPE, Université de Montpellier, CNRS, Ifremer, Université de Perpignan Via

Domitia, Place E. Bataillon, CC080, 34095 Montpellier, France

Full list of author information is available at the end of the article
}

stages, decimating up to $100 \%$ of young oysters in French farms [2]. In recent years, this mortality syndrome, designated Pacific oyster mortality syndrome (POMS), has became panzootic, being observed in all coastal regions of France and numerous other countries worldwide [3]. Today, POMS consequences are dramatic and represents a significant threat for the global oyster industry [2]. Research efforts have revealed a series of factors contributing to the disease, including infectious agents interacting with seawater temperature and oyster genetics [2, 4-8]. Recently, holistic molecular approaches performed on susceptible and resistant families of oysters, deciphered the mechanism of POMS by combining dual RNAseq (oyster, OsHV-1 and vibrio), $16 \mathrm{~S}$ rDNA metabarcoding, histology and invalidation of virulence genes from bacteria $[9,10]$. These studies showed 
that an infection by the Ostreid herpesvirus (Ostreid herpesvirus type $1 \mu \mathrm{Var}$ ) is the critical step in the infectious process leading to an immune-compromised state by altering hemocyte physiology [9]. This first process is followed by a microbiota destabilization which "opens the door" to bacterial pathogens (e.g. vibrios) that target hemocyte to induce their lysis [10]. The infectious process is completed with subsequent bacteraemia, which is the ultimate step inducing oyster death [9].

However, some oysters are disease-resistant to POMS. Genetic studies on oyster resistance revealed a significant additive genetic component for survival during OsHV-1 infection $[4,11,12]$. Over the past decade, many genomic resources have been developed including a reference genome [13] and SNP arrays [14]. These resources enabled an investigation of the genetic architecture of $C$. gigas resistance to OsHV-1 infection; juvenile oysters were experimentally challenged with OsHV-1 and genotyped using a high density linkage map constructed for the Pacific oyster [15]. The genome-wide association developed suggested a polygenic nature of resistance to OsHV-1 and highlighted region of linkage group 6 containing a significant QTL affecting host resistance [15]. Several SNPs showing an association with survival and/or viral load were located in several genes encoding a RAN Binding Protein 9, a Coronin and an actin motor protein Myo10. However, their involvement in the resistance process remains unknown. A recent transcriptomic approach employed on different oyster biparental families displaying contrasted susceptibilities to POMS showed that the early induction of genes involved in antiviral defense is a hallmark of resistant families [9]. However, the genetic components responsible for this early induction remain unidentified.

To fill this gap in knowledge and to identify putative transcriptomic determinants associated to POMS resistance, we compared the basal transcriptomes of six biparental families of oysters displaying contrasted susceptibilities to the disease (3 resistant and 3 susceptible). Here, we showed that genes involved in stress response, protein modifications, maintenance of DNA integrity and repair, and immune and antiviral pathways are differentially expressed in resistant oysters.

\section{Results}

Infectious environments select oysters resistant to POMS In 2015, oyster broodstocks were collected in two distinct geographic areas (Brittany-Atlantic coast and Gulf of lion- Mediterranean coast) and two sampling sites (farming, high biomass and non-farming, low biomass) from each area (Fig. 1). These broodstocks were used to produce 12 biparental families (3 families from each origin and sampling sites). Three additional biparental families were produced from broodstocks originating from a mass selection program for higher survival for POMS [16] (Fig. 1). These 15 oyster families were subjected to four infectious challenges performed with two infectious environments (Atlantic and Mediterranean) and two experimental procedures (mesocosm and field infections) (Fig. 2 and Table 1).

High variability in percentages of mortality, ranging from 1 to $100 \%$, was observed among families (Table 1). Family F15 showed the most susceptibility with a mortality rate higher than $97 \%$ for any infection trial. In contrast, Family F21 showed the highest resistance whatever the infection trial. Taking into account the 15 families and the 2 infectious environments, the percentage of mortalities observed in the field were not significantly different than those obtained in mesocosm conditions (Mann-Whitney test, $p=0.06)$. Overall, disease susceptibility was quite similar for the different families in the different

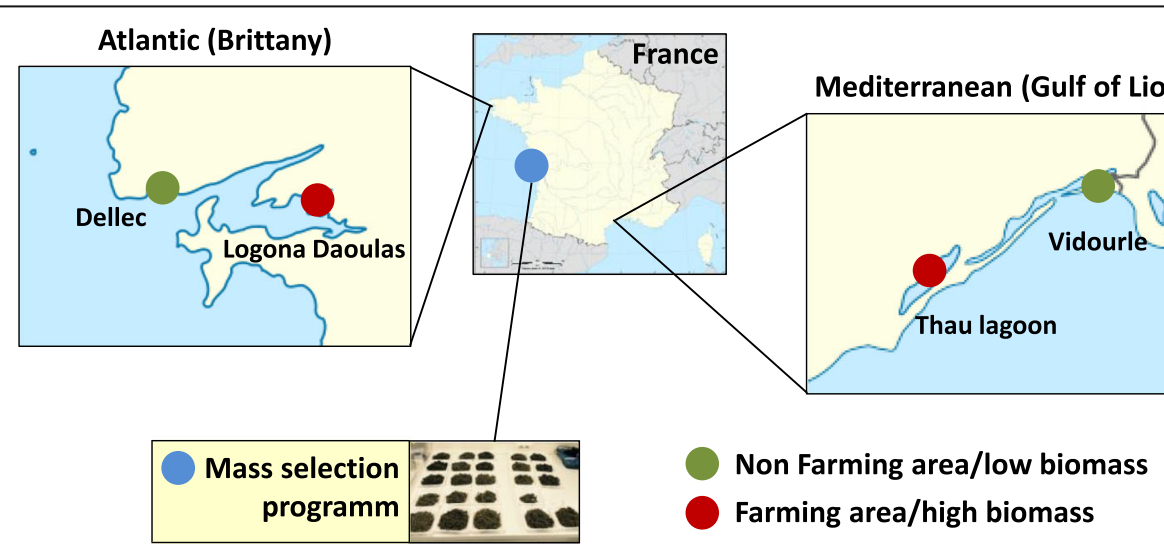

Fig. 1 Broodstock origins for the production of biparental oyster families. Wild stocks were sampled in farming (purple) and non-farming (orange) sites in two geographic areas (Atlantic and Mediterranean coasts). Mass selected oysters (yellow) originated from the Ifremer hatchery of La Tremblade [16]. Image source: commons.wikimedia.org 


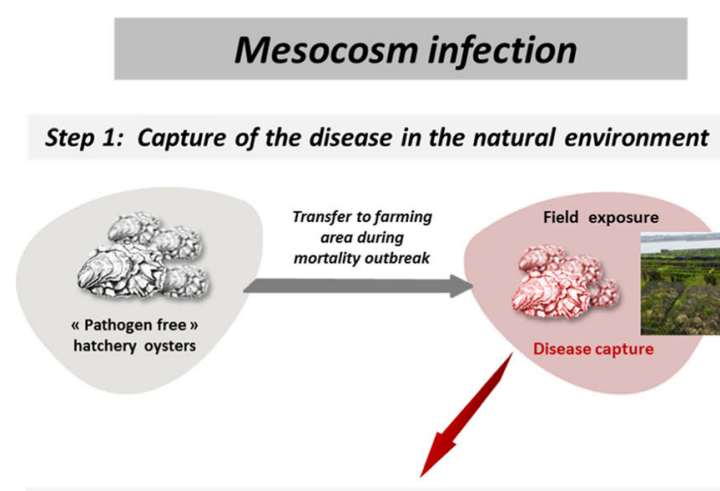

Step 2: Disease transmission infection in controlled condition
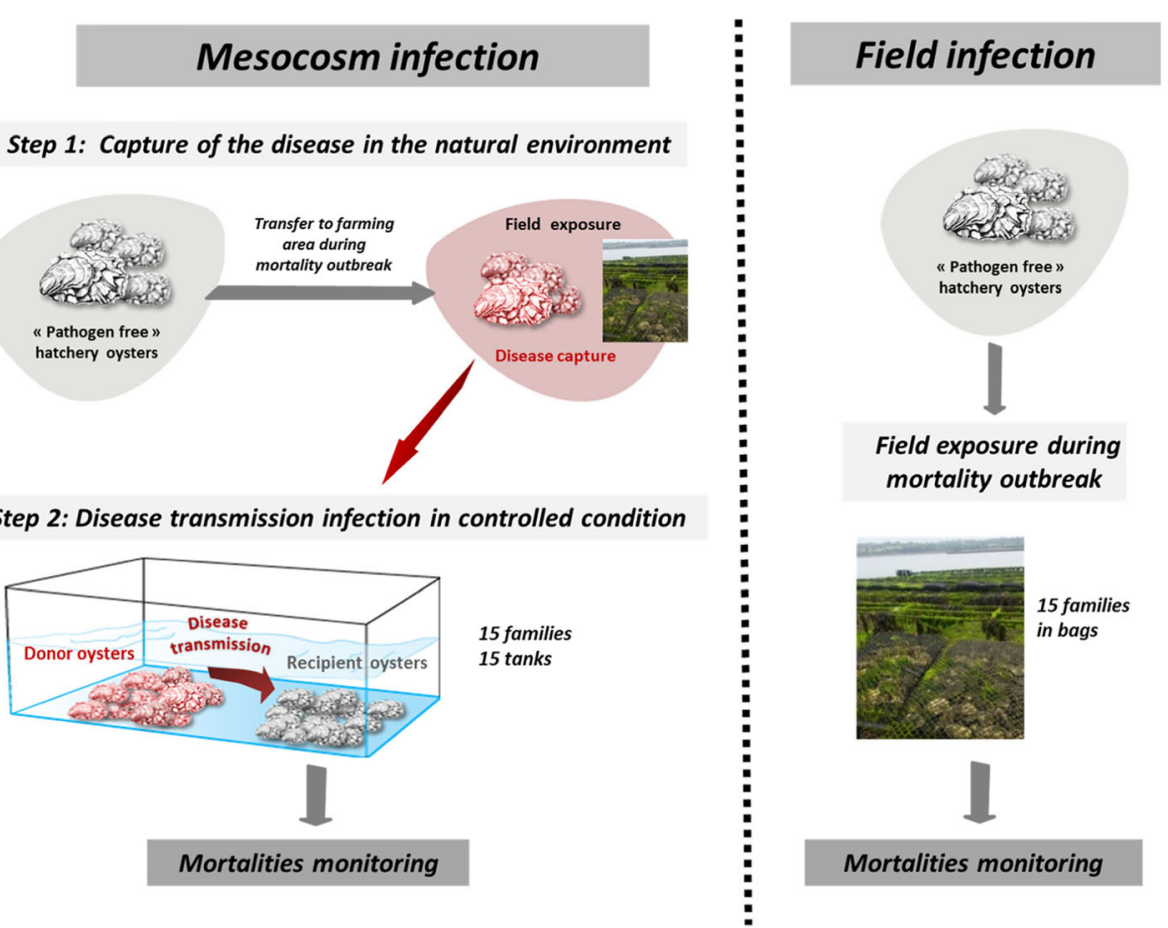

Fig. 2 Schematic of the mesocosm (left panel) and field (right panel) protocols of infection. For the experimental infection, pathogen free oysters (mix of the fifteen families) were deployed in the natural environment in a farming area during disease outbreaks and brought back to a controlled environment to transfer the disease to each of the 15 oyster families under controlled conditions. For field infection, each of the 15 oyster families were exposed to an infectious environment during a disease outbreak. Experimental infections were performed with infectious environments from Atlantic and Mediterranean origin

infection trials (Table 1). Mortalities observed for the 15 families were 1.75 fold more important for the Atlantic infectious environment than for the Mediterranean infectious one (Mann Whitney, $p=$ 0.02) (Table 1).

As expected, the 3 families (F21, F23 and F28) produced from broodstocks coming from the mass selection program [16] displayed low percentages of mortality (Figs. 3 and 4). Similarly, families obtained from wild oysters sampled in a farming area and putatively submitted to disease selection were also more resistant than those from non-farming areas ((Mann Whitney, $p=$ 0.018), Fig. 4).

To confirm POMS disease in the different mesocosm experiments, we quantified OsHV-1 and total vibrio loads by qPCR (Additional file 1). We observed the colonization of oyster flesh by OsHV-1 and vibrios in both Atlantic and Mediterranean mesocosm experiments $72 \mathrm{~h}$ post-exposure.

The 6 families, retained for the subsequent comparative transcriptomics, were the three best oyster families for POMS resistance (F21, F23 and F48 renamed $R_{F 21}$, $\mathrm{R}_{\mathrm{F} 23}$ and $\mathrm{R}_{\mathrm{F} 48}$, respectively) and the three worst (F11, F14 and F15, renamed $\mathrm{S}_{\mathrm{F} 11}, \mathrm{~S}_{\mathrm{F} 14}$ and $\mathrm{S}_{\mathrm{F} 15}$, respectively) (Fig. 3).

\section{Stress and immune functions are enriched in the basal transcriptome of resistant oysters}

To identify putative transcriptomic determinants associated with POMS resistance, we compared the basal transcriptome profiles of the 6 selected families $\left(\mathrm{R}_{\mathrm{F} 21}, \mathrm{R}_{\mathrm{F} 23}\right.$, $\mathrm{R}_{\mathrm{F} 48}, \mathrm{~S}_{\mathrm{F} 11}, \mathrm{~S}_{\mathrm{F} 14}$ and $\mathrm{S}_{\mathrm{F} 15}$ ), maintained in the same hatchery conditions and without disease challenge. We sequenced a total of 36 RNA-seq libraries (6 families, 2 independent experiments and 3 replicates for each experiment). Sequencing yielded between 30.1 and 39.3 million Illumina single reads per sample of which 70.1$74.9 \%$ mapped to the $C$. gigas V9 reference genome.

From these RNA-seq data, we compared the basal transcriptome of each resistant family to the three susceptible families using DEseq (DEseq $p$-value $<0.05$ ). The differentially expressed genes (DEGs) common between each comparison were retained for further analysis. This strategy identified 3304, 2711 and 3259 DEGs modulated in the same way (up- or down-represented for the three comparisons) in $\mathrm{R}_{\mathrm{F} 21}, \mathrm{R}_{\mathrm{F} 23}$ and $\mathrm{R}_{\mathrm{F} 48}$, respectively (Fig. 5a). Among these DEGs, (i) 299 were differentially expressed by the three resistant families, (ii) 924 were differentially expressed by both $R_{F 21}$ and $R_{F 23}$, (iii) 261 were differentially expressed by both $R_{F 23}$ and $\mathrm{R}_{\mathrm{F} 48}$, and (iv) 308 were differentially expressed by both 
Table 1 Oysters broodstock origin and families susceptibility to the mesocosm and field infection trials

\begin{tabular}{|c|c|c|c|c|c|c|c|}
\hline \multirow{2}{*}{$\begin{array}{l}\text { Oyster } \\
\text { Family }\end{array}$} & \multicolumn{3}{|c|}{ Broodstock origin } & \multicolumn{4}{|l|}{ Mortality (\%) } \\
\hline & $\begin{array}{l}\text { Geographic } \\
\text { area }\end{array}$ & $\begin{array}{l}\text { Sampling } \\
\text { site }\end{array}$ & $\begin{array}{l}\text { Geographical } \\
\text { coordinate }\end{array}$ & $\begin{array}{l}\text { Atlantic mesoscosm } \\
\text { infection }\end{array}$ & $\begin{array}{l}\text { Atlantic field } \\
\text { infection }\end{array}$ & $\begin{array}{l}\text { Mediterranean mesocosm } \\
\text { infection }\end{array}$ & $\begin{array}{l}\text { Mediterranean } \\
\text { field infection }\end{array}$ \\
\hline $\mathrm{F} 1$ & Atlantic & $\begin{array}{l}\text { Farming } \\
\text { area }\end{array}$ & $\begin{array}{l}\text { Logonna Daoulas (lat } 48.335263 \\
\text { - long - 4.317922) }\end{array}$ & 98 & 99 & 75 & 89 \\
\hline$F 2$ & Atlantic & $\begin{array}{l}\text { Farming } \\
\text { area }\end{array}$ & $\begin{array}{l}\text { Logonna Daoulas (lat } 48.335263 \\
\text { - long - 4.317922) }\end{array}$ & 68 & 100 & 70 & 88 \\
\hline F9 & Atlantic & $\begin{array}{l}\text { Farming } \\
\text { area }\end{array}$ & $\begin{array}{l}\text { Logonna Daoulas (lat } 48.335263 \\
\text { - long - 4.317922) }\end{array}$ & 56 & 95 & 14 & 44 \\
\hline F11 & Atlantic & $\begin{array}{l}\text { Non } \\
\text { farming } \\
\text { area }\end{array}$ & $\begin{array}{l}\text { Dellec (lat 48.353970, long - } \\
4.566123)\end{array}$ & 99 & 100 & 90 & 93 \\
\hline F14 & Atlantic & $\begin{array}{l}\text { Non } \\
\text { farming } \\
\text { area }\end{array}$ & $\begin{array}{l}\text { Dellec (lat 48.353970, long - } \\
4.566123)\end{array}$ & 96 & 100 & 94 & 94 \\
\hline F15 & Atlantic & $\begin{array}{l}\text { Non } \\
\text { farming } \\
\text { area }\end{array}$ & $\begin{array}{l}\text { Dellec (lat 48.353970, long - } \\
4.566123)\end{array}$ & 100 & 100 & 97 & 98 \\
\hline$F 21$ & $\begin{array}{l}\text { Breeding } \\
\text { program }\end{array}$ & $\begin{array}{l}\text { Breeding } \\
\text { program }\end{array}$ & $\begin{array}{l}\text { Charente Maritime- La } \\
\text { Tremblade (lat 45.781741, long } \\
\text { - 1.121910) }\end{array}$ & 3 & 2 & 1 & 7 \\
\hline F23 & $\begin{array}{l}\text { Breeding } \\
\text { program }\end{array}$ & $\begin{array}{l}\text { Breeding } \\
\text { program }\end{array}$ & $\begin{array}{l}\text { Charente Maritime- La } \\
\text { Tremblade (lat 45.781741, long } \\
\text { - 1.121910) }\end{array}$ & 12 & 24 & 12 & 11 \\
\hline$F 28$ & $\begin{array}{l}\text { Breeding } \\
\text { program }\end{array}$ & $\begin{array}{l}\text { Breeding } \\
\text { program }\end{array}$ & $\begin{array}{l}\text { Charente Maritime- La } \\
\text { Tremblade (lat 45.781741, long } \\
-1.121910 \text { ) }\end{array}$ & 32 & 38 & 18 & 28 \\
\hline F32 & Mediterranean & $\begin{array}{l}\text { Non } \\
\text { farming } \\
\text { area }\end{array}$ & $\begin{array}{l}\text { Vidourle (lat 43.553906, long } \\
\text { 4.095175) }\end{array}$ & 56 & 98 & 78 & 89 \\
\hline F33 & Mediterranean & $\begin{array}{l}\text { Non } \\
\text { farming } \\
\text { area }\end{array}$ & $\begin{array}{l}\text { Vidourle (lat 43.553906, long } \\
\text { 4.095175) }\end{array}$ & 48 & 92 & 39 & 59 \\
\hline F37 & Mediterranean & $\begin{array}{l}\text { Non } \\
\text { farming } \\
\text { area }\end{array}$ & $\begin{array}{l}\text { Vidourle (lat 43.553906, long } \\
\text { 4.095175) }\end{array}$ & 30 & 95 & 2 & 30 \\
\hline F42 & Mediterranean & $\begin{array}{l}\text { Farming } \\
\text { area }\end{array}$ & $\begin{array}{l}\text { Thau lagoon (lat 43.418736, } \\
\text { long 3.622620) }\end{array}$ & 37 & 96 & 44 & 65 \\
\hline F44 & Mediterranean & $\begin{array}{l}\text { Farming } \\
\text { area }\end{array}$ & $\begin{array}{l}\text { Thau lagoon (lat 43.418736, } \\
\text { long 3.622620) }\end{array}$ & 40 & 86 & 2 & 10 \\
\hline F48 & Mediterranean & $\begin{array}{l}\text { Farming } \\
\text { area }\end{array}$ & $\begin{array}{l}\text { Thau lagoon (lat 43.418736, } \\
\text { long 3.622620) }\end{array}$ & 18 & 40 & 7 & 12 \\
\hline
\end{tabular}

$\mathrm{R}_{\mathrm{F} 21}$ and $\mathrm{R}_{\mathrm{F} 48}$ (Fig. 5a and Additional file 2). The remaining 1773, 1227 and 2391 DEGs displayed a specific differential expression in $\mathrm{R}_{\mathrm{F} 21}, \mathrm{R}_{\mathrm{F} 23}$ and $\mathrm{R}_{\mathrm{F} 48}$, respectively (Fig. 5a and Additional file 3, Additional file 4 and Additional file 5). A previous study has evidenced that the resistance to POMS is associated to an early antiviral response that blocks OsHV-1 replication [17-19]. Indeed, 308 DEGs associated to antiviral defence are early induced in resistant oysters and among them, 61 are differentially expressed at basal level between resistant and susceptible families in the present study. These genes are highlighted in red in the Additional file 2, Additional file 3, Additional file 4, and Additional file 5. A part of them are related to TLR-NF-kB, JAK-STAT and RLR-STING antiviral signalling pathways (indicated in red in Fig. 6). To determine the enriched functions, we used a gene ontology (GO) enrichment analysis. As the mechanisms underlying resistance can be specific or shared by oyster families, we performed the enrichment analysis on DEGs for each resistant family separately and also on DEGs shared by at least two of the three resistant families. First, the analyses performed on DEGs of each resistant family separately showed a limited number of enriched functions (7, 6 and 5 for $\mathrm{R}_{\mathrm{F} 21}, \mathrm{R}_{\mathrm{F} 23}$ and $\mathrm{R}_{\mathrm{F} 48}$, respectively; Fig. $5 \mathrm{~b}, \mathrm{c}$ and $\mathrm{d}$, 


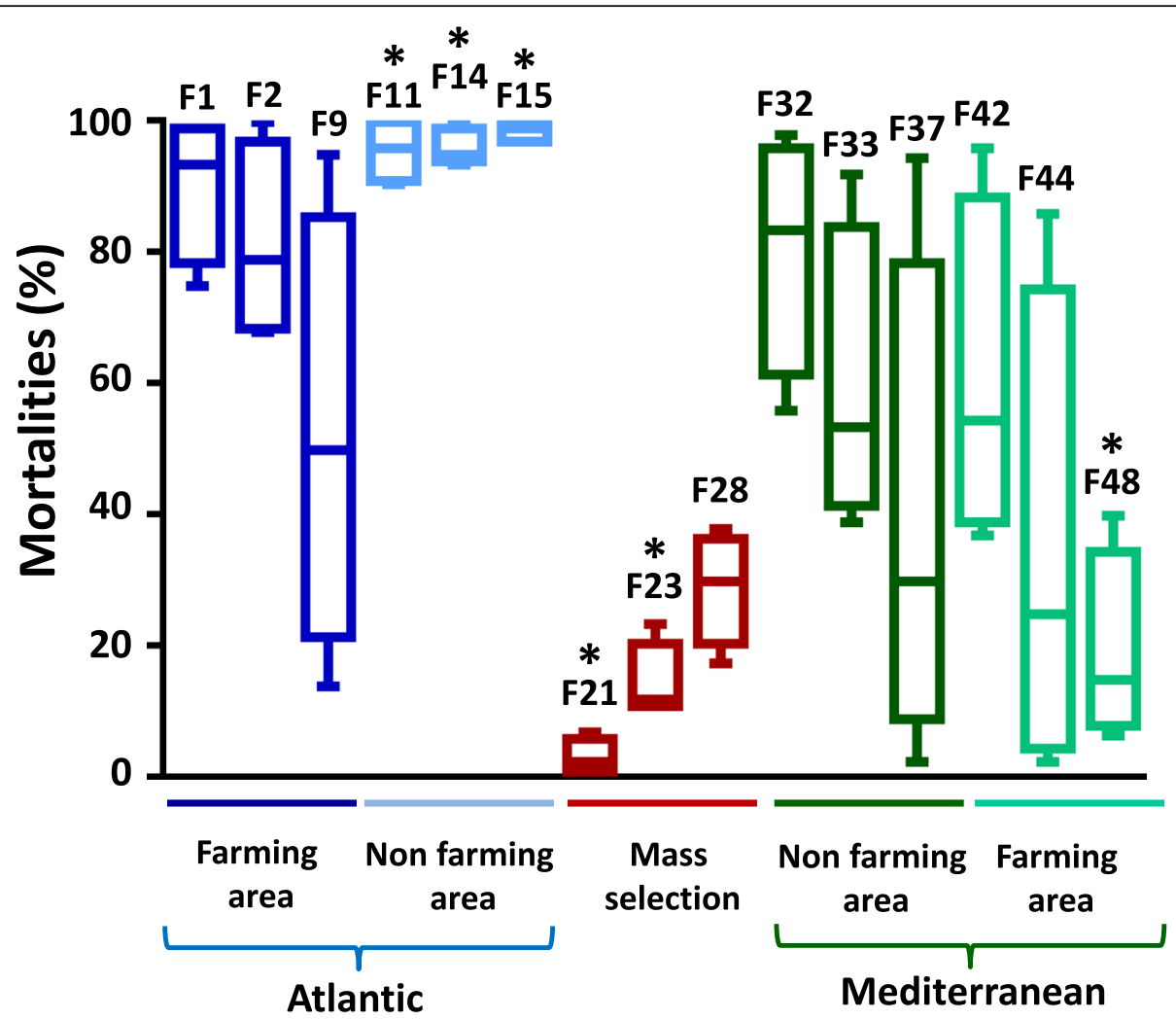

Fig. 3 Mean mortality of each oyster family in different infection trials. The broodstocks origin - blue: Atlantic, green: Mediterranean, dark: Farming/high biomass, light: Non farming/low biomass, and red: mass selection program - are indicated below the graph. Each box plot represents the mean mortality and the variance for each biparental family submitted to the four infection trials. The three most susceptible and the three most resistant oyster families used for transcriptome analyses are indicated by asterisks

respectively). Interestingly, four functional categories ("defense response to other organism", "response to external stimulus", "defense response" and "response to stress") were enriched for the 3 resistant families. It is noteworthy that $\mathrm{R}_{\mathrm{F} 21}$ and $\mathrm{R}_{\mathrm{F} 23}$ shared two additional enriched categories ("receptor-mediated endocytosis" and "protein modification by small protein conjugation or removal"). Finally, a functional category related to the "actin polymerization and depolarization" showed enrichment in $\mathrm{R}_{\mathrm{F} 48}$ only, while a functional category related to "ubiquitin-dependent protein catabolic process" showed enrichment in $\mathrm{R}_{\mathrm{F} 21}$ only. Second, the GO enrichment analysis on DEGs shared by at least two of the three resistant families (1792 DEGs, Additional file 2) revealed five enriched functional categories (Fig. 5e): "defense response to other organism", "response to external stimulus", "defense response", "response to stress" and "protein modification by small protein conjugation or removal". DEGs falling in these five enriched categories (374 genes) are shown in Additional file 2 (CGI indicated in yellow).

\section{Resistant oysters differentially express common and specific immune genes}

To further delineate the molecular mechanisms underlying POMS resistance shared by the different resistant families, we first analysed the 374 DEGs belonging to the above identified functions (ie. defense response, response to stress, defense response to other organism, response to external stimulus and protein modification by small protein conjugation or removal) and shared by at least two of the three resistant families (CGI indicated in yellow in Additional file 2). Among these genes, we found members of large multigene families known to be involved (i) in stress response like heat shock proteins (HSP) and glutathione S-transferases, (ii) in protein modifications like ubiquitin ligases and Tripartite Motif containing proteins (TRIM), (iii) in maintenance of DNA integrity and repair like Poly [ADP-ribose] polymerases (PARP), nucleases and helicases, (iv) in PAMP (Microbe Associated Molecular Pattern) recognition (PRR) like C1q domain containing proteins, lectins, scavenger receptors (SR), Fibrinogen domain containing proteins, hemagglutinins and $(\mathrm{v})$ in antiviral defense like IFI44 proteins. We also identified a series of genes putatively involved in antiviral defense and signaling (TLRNF-кB, JAK-STAT and RLR-STING pathways, Fig. 6a). A putative endosomal Toll-like receptor 13 was overexpressed in the 3 resistant families. A tRNA adenosine deaminases (ADAT) was over-represented in $R_{F 21}$ and 


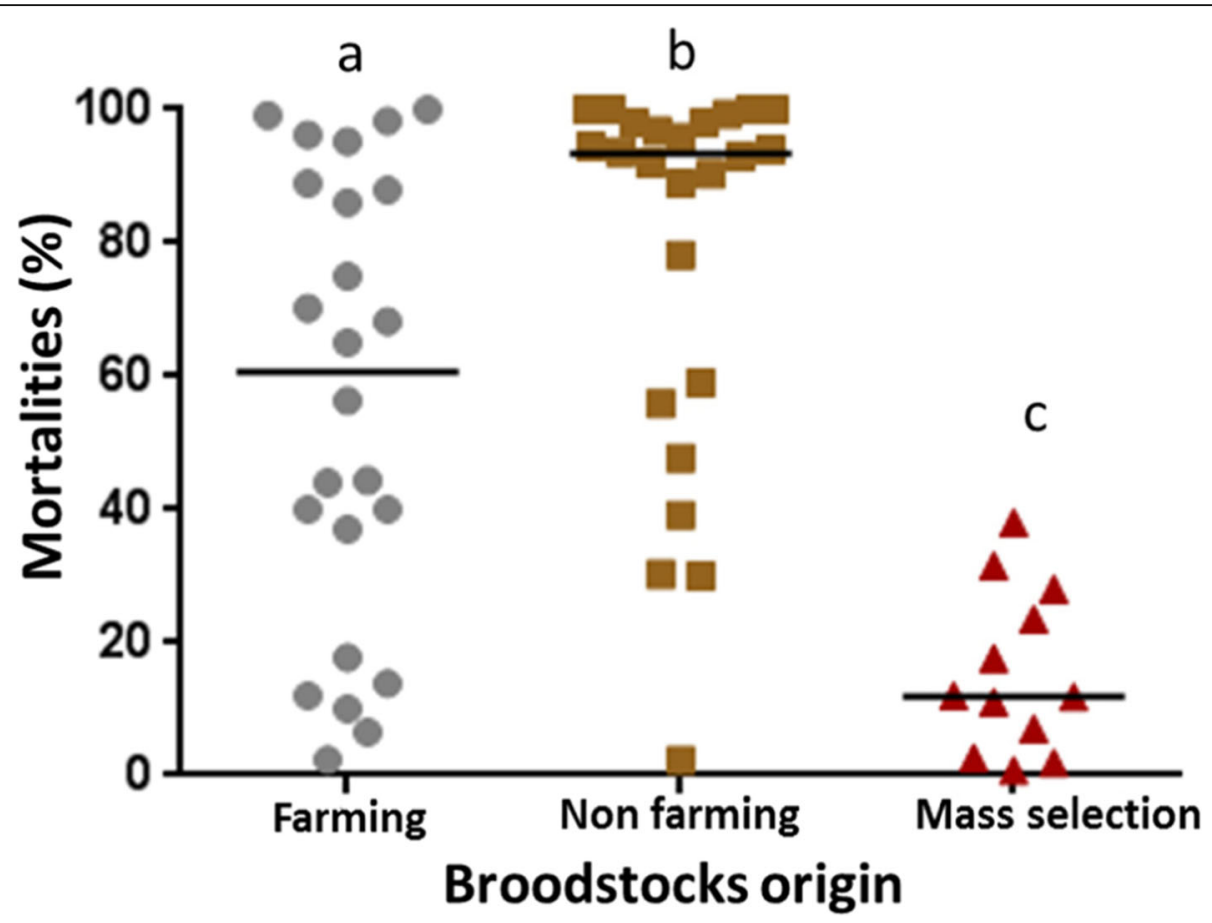

Fig. 4 Oyster families produced from broodstocks surviving POMS challenge are more disease resistant. Mortalities of the different families after exposure to POMS in the different infection trials were analysed by origin of the broodstocks (farming/high biomass, and non-farming/low biomass area or mass selection program). Significant differences between conditions are indicated by different lowercase letters (different letters indicate significant difference, $a$, b or c; Mann-Whitney $U$ test, $p<0.05$ )

$\mathrm{R}_{\mathrm{F} 23}$. A stimulator of interferon genes (STING) is underrepresented in $\mathrm{R}_{\mathrm{F} 23}$ and $\mathrm{R}_{\mathrm{F} 48}$ (see Fig. 6a for CGI number for each DEG).

Finally, we analyzed DEGs for each resistant family belonging to the enriched categories described in Fig. 5 (i.e. defense response, response to stress, defense response to other organism, response to external stimulus, protein modification by small protein conjugation or removal, receptor-mediated endocytosis, ubiquitin-dependent protein catabolic process via the multivesicular body sorting pathway and actin polymerization or depolymerisation; the corresponding CGIs are highlighted in yellow in Additional file 3, Additional file 4, and Additional file 5). This analysis highlighted specific processes associated with resistance in each resistant genotype. These genes represented 371, 251 and 315 DEGs in $R_{\mathrm{F} 21}, R_{\mathrm{F} 23}$ and $R_{\mathrm{F} 48}$, respectively. In these specific sets of DEGs, we again found several genes belonging to the same large multigene families reported above (HSP, glutathione Stransferases, ubiquitin ligases, TRIM, PARP, nucleases, helicases, PRR and IFI44). In addition, several genes involved in antiviral and signaling pathways were also found differentially expressed in each resistant family specifically (TLR-NF- $\mathrm{kB}$, JAK-STAT and RLR-STING pathways, Fig. 6b). Transcripts corresponding to a Toll-like receptor (TLR), 2 myeloid differentiation primary response 88 (MyD88), a TNF receptorassociated factor (TRAF), a deoxynucleoside triphosphate triphosphohydrolase (SAMHD1), and 2 stimulator of interferon genes (STING) were differentially represented in the $R_{F 21}$ family (see Fig. 6b for CGI number for each DEG). Transcripts corresponding to 2 TLRs, a MyD88, a TRAF, a 2',5'oligoadenylate synthase $\left(2^{\prime}, 5^{\prime}\right.$-OAS) and an interferon regulatory factor (IRF), were differentially represented in the $\mathrm{R}_{\mathrm{F} 23}$ family (see Fig. 6b for CGI number for each DEG). However, in these 2 families, the majority (9/13) of these DEGs was under-represented in comparison with susceptible oysters (Fig. 6b). In contrast, the majority (10/11) of DEGs in the $\mathrm{R}_{\mathrm{F} 48}$ family was over-represented in this resistant family. They corresponded to an interleukin-1 receptor-associated kinase (IRAK), a NF-kB p105 subunit, 2 Serine threonine- kinases TBK1, a signal transducer and transcription activator (STAT), 2 suppressors of cytokine signaling (SOCS), a STING and 2 IRFs (see Fig. 6b for CGI number for each DEG). Only a 2',5'- oligoadenylate synthase (OAS) appeared under-represented in $\mathrm{R}_{\mathrm{F} 48}$.

\section{Discussion}

Fifteen oyster families were produced and phenotyped using mesocosm and field infections. No significant differences in terms of mortality between mesocosm and field infections were evidenced. This result suggested that the disease developed in mesocosm experiments accurately reproduces the disease in the natural environment with the same outcomes. The mortalities observed with the Atlantic infectious environment were significantly higher 


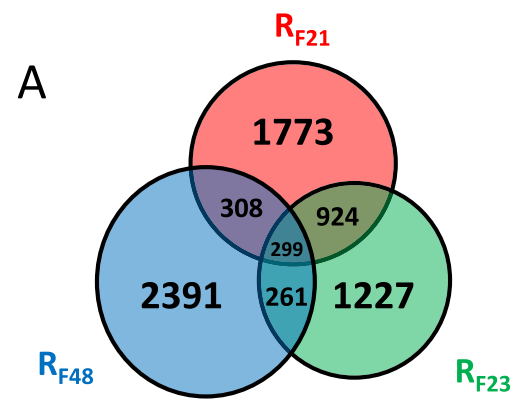

B

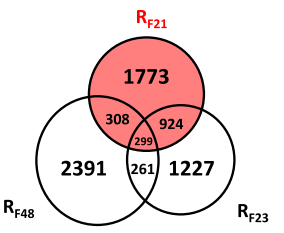

C

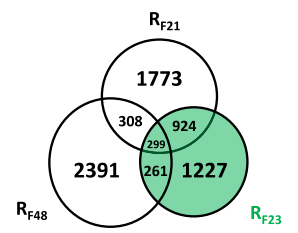

D

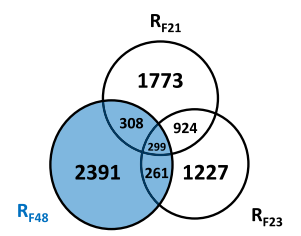

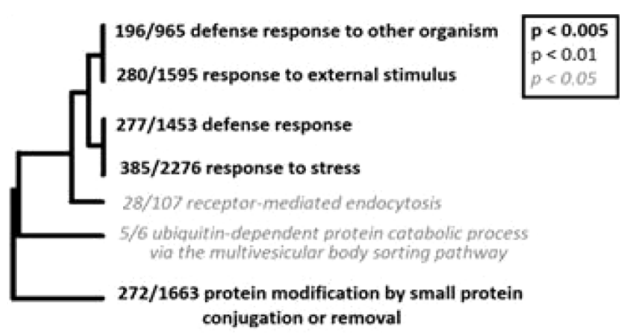
conjugation or removal

$\mathbf{R}_{\mathrm{F} 23}$
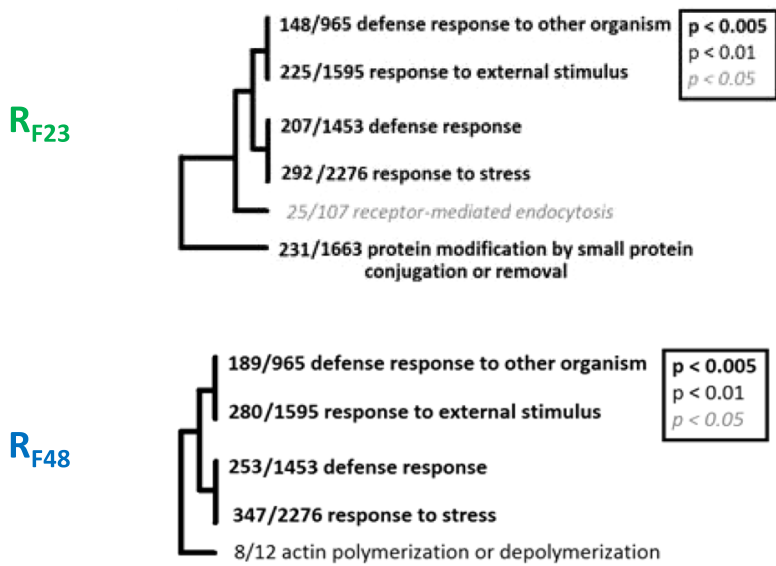

E

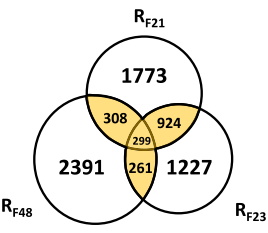

Shared by at least 2 resistant families

Fig. 5 Venn diagram of DEGs between resistant and susceptible oyster families and enrichment analysis. a Venn diagram of DEGs between resistant and susceptible oyster families, where each circle corresponds to a resistant family ( $R_{F 21}$ in red, $R_{F 23}$ in green or $R_{F 48}$ in blue). The numbers inside indicate the number of DEGs between each resistant family and the three susceptible families $\left(\mathrm{S}_{\mathrm{F} 11}, \mathrm{~S}_{\mathrm{F} 14}\right.$ and $\left.\mathrm{S}_{\mathrm{F} 15}\right)$. The numbers in overlapped circles indicate the numbers of DEGs commons to two or three resistant families. A total of 7183 DEGs were identified. Hierarchical clustering trees of GO categories (biological process) significantly enriched for the (b) 3304 DEGs of the $R_{F 21}$ family, (c) 2711 DEGs of the RF23 family, (d) 3259 DEGs of the $R_{F 48}$ family and (e) 1792 DEGs shared by at least two resistant families. The ratio before each GO category represents the number of DEGs in this category divided by the total number of genes related to this category annotated in the genome

than those obtained from Mediterranean one, while OsHV1 and total vibrio colonised oyster tissues in both experiments. Differences in the two infectious environments could explain these differences in mortalities. Indeed, the presence of different OsHV-1 virus variants, already reported in different infectious environments [20], could 


\begin{tabular}{|c|c|c|c|c|c|c|c|}
\hline \multirow[t]{4}{*}{$A$} & & CGI & Name & Signaling pathway & Log2 FC_RF21 & Log2 FC_RF23 & Log2 FC_RF48 \\
\hline & Shared by 3 resistant families & CGI_10005194 & TLR 13 & TLR-NFKB & & & \\
\hline & \multirow{2}{*}{ Shared by 2 resistant families } & CGI_10009627 & ADAT & JAK-STAT & & & NS \\
\hline & & CGI_10004069 & STING & RLR-STING & NS & & \\
\hline \multirow[t]{28}{*}{ B } & \multirow{8}{*}{ Specific to RF21 } & CGI & Name & Signaling pathway & $\begin{array}{c}\text { Log2 FC_RF21 } \\
\text { vs. SF11 }\end{array}$ & $\begin{array}{c}\text { Log2 FC_RF21 } \\
\text { vs. SF14 }\end{array}$ & $\begin{array}{c}\text { Log2 FC_RF21 } \\
\text { vs. SF15 }\end{array}$ \\
\hline & & CGI_10022880 & SAMHD1 & RLR-STING & & & \\
\hline & & CGI_10026099 & MyD88 & TLR-NFKB & & & \\
\hline & & CGI_10022970 & STING & RLR-STING & & & \\
\hline & & CGI_10026493 & TLR & TLR-NFKB & & & \\
\hline & & CGI_10006439 & STING & RLR-STING & & & \\
\hline & & CGI_10013672 & MyD88 & TLR-NFKB & & & \\
\hline & & CGI_10027979 & TRAF & TLR-NFKB & & & \\
\hline & \multirow{7}{*}{ Specific to RF23 } & CGI & Name & Signaling pathway & $\begin{array}{c}\text { Log2 FC_RF23 } \\
\text { vs. SF11 }\end{array}$ & $\begin{array}{c}\text { Log2 FC_RF23 } \\
\text { vs. SF14 }\end{array}$ & $\begin{array}{c}\text { Log2 FC_RF23 } \\
\text { vs. SF15 }\end{array}$ \\
\hline & & CGI_10013672 & MyD88 & TLR-NFKB & & & \\
\hline & & CGI_10021739 & TLR & TLR-NFKB & & & \\
\hline & & CGI_10027674 & TRAF & TLR-NFKB & & & \\
\hline & & CGI_10005133 & IRF & RLR-STING & & & \\
\hline & & CGI_10009217 & TLR & TLR-NFKB & & & \\
\hline & & CGI_10004067 & 2'-5' OAS & JAK-STAT & & & \\
\hline & \multirow{12}{*}{ Specific to RF48 } & CGI & Name & Signaling pathway & $\begin{array}{c}\text { Log2 FC_RF48 } \\
\text { vs. SF11 }\end{array}$ & $\begin{array}{c}\text { Log2 FC_RF48 } \\
\text { vs. SF14 }\end{array}$ & $\begin{array}{c}\text { Log2 FC_RF48 } \\
\text { vs. SF15 }\end{array}$ \\
\hline & & CGI_10005003 & STAT & JAK-STAT & & & \\
\hline & & CGI_10022970 & STING & RLR-STING & & & \\
\hline & & CGI_10000166 & IRAK4 & TLR-NFKB & & & \\
\hline & & CGI_10003270 & IRF3 & RLR-STING & & & \\
\hline & & CGI_10019528 & SOCS & JAK-STAT & & & \\
\hline & & CGI_10010090 & SOCS & JAK-STAT & & & \\
\hline & & CGI_10004656 & TBK1 & TLR-NFKB & & & \\
\hline & & CGI_10028750 & NFKB & TLR-NFKB & & & \\
\hline & & CGI_10016954 & TBK1 & TLR-NFKB & & & \\
\hline & & CGI_10020482 & IRF2 binding & RLR-STING & & & \\
\hline & & CGI_10017356 & 2'-5' OAS & JAK-STAT & & & \\
\hline & & & & & 2 & 0 & 1 \\
\hline \multicolumn{8}{|c|}{$\begin{array}{l}\text { Fig. } 6 \text { DEGs related to TLR-NFKB, JAK-STAT and RLR-STING pathways. a DEGs shared by at least two resistant oyster families. Each resistant family } \\
\left(R_{F 21}, R_{F 23} \text { and } R_{F 48} \text { ) is compared to the three susceptible families }\left(S_{F 11}, S_{F 14} \text { and } S_{F 15}\right) \text {; mean log2 fold change is given. b } D E G S \text { specific to each }\right. \\
\left.\text { resistant family. Each resistant family ( } R_{F 21}, R_{F 23} \text { and } R_{F 48}\right) \text { is compared to the three susceptible families separately }\left(S_{F 11}, S_{F 14} \text { and } S_{F 15}\right) \text {. The } \\
\text { intensity of the colour from green to red indicates the magnitude of the log2 fold change for the corresponding transcript. NS: not significant. } \\
\text { CGl indicated in red are also associated to an early antiviral response of resistant oysters [9] }\end{array}$} \\
\hline
\end{tabular}

explain the differences observed. Future studies will investigate this specific question. A second explanation can be the age difference of oysters submitted to these two infectious environments. Indeed, the oysters submitted to the Mediterranean infections were 2 months older. As resistance to the disease increases with age $[4,21]$, we cannot exclude that older oysters were slightly less susceptible. As expected, higher survival rates occurred in oyster families produced from broodstocks coming from a breeding program using mass selection [16] or from broodstocks recruited in farming areas compared to those from broodstocks recruited in non-farming areas. This last result shows that the 
selective pressure exerted by the infectious environment during the first years after recruitment is sufficient to select oysters more resistant to POMS. Indeed, selection for OsHV-1 has a genetic basis [22, 23]. In contrast, wild oysters collected in non-farming areas still showed high susceptibility to POMS suggesting either the absence of disease pressure or a much lower disease pressure than in farming area as previously shown [24].

In order to identify the transcriptomic determinants of POMS resistance, we selected the three most resistant (R) and susceptible (S) oyster families and compared their basal transcriptome when they were maintained in the same controlled conditions and without exposure to the disease. Two $\mathrm{R}$ families came from broodstocks selected through "mass selection" $\left(\mathrm{R}_{\mathrm{F} 21}\right.$ and $\left.\mathrm{R}_{\mathrm{F} 23}\right)$, and one $\mathrm{R}$ family came from broodstocks recruited in a farming area and selected through "natural selection" $\left(\mathrm{R}_{\mathrm{F} 48}\right)$. The three $\mathrm{S}$ families $\left(\mathrm{S}_{\mathrm{F} 11}, \mathrm{~S}_{\mathrm{F} 14}\right.$ and $\left.\mathrm{S}_{\mathrm{F} 15}\right)$ were produced from broodstocks recruited in non-farming areas. Our transcriptomic analysis revealed a clear modulation and enrichment of genes belonging to functions related to defense, stress and protein modifications among the resistant and susceptible families. A series of genes related to these functional categories belong to large multigene families like Tripartite Motif containing proteins (TRIM), ubiquitin ligases, IFI44, heat shock proteins, glutathione Stransferases, proteins involved in maintenance of DNA integrity and repair like Poly [ADP-ribose] polymerases (PARP), nucleases and helicases, C1q domain containing proteins, lectins, scavenger receptors, fibrinogen domain containing proteins and hemagglutinins. Other genes involved in immune and antiviral pathways (TLR-NF- $\kappa B$, JAK-STAT and RLR-STING) were also found to be modulated in our study. Such differences in basal expression of immune genes have been already described in resistant and susceptible cultivars of litchi, apple or soybean to pathogens [17-19]. Variations of immune status between human populations have also been described at genetic and epigenetic levels, and these changes modulate several key regulators of innate immunity $[25,26]$. These differences in immune status likely arise from the different selected pressures experienced that impact the host response to pathogens, especially in African populations, which develop a strong inflammatory response compared to European populations [25]. Even if the genetic determinism of POMS resistance is clear $[4,11,12]$, we cannot exclude that the difference in expression reported in our study may be controlled by epigenetic mechanisms known to influence gene expression in invertebrates [27]. This possibility shall be investigated in future studies.

As $R_{\mathrm{F} 21}, \mathrm{R}_{\mathrm{F} 23}$ and $\mathrm{R}_{\mathrm{F} 48}$ can control virus replication in oyster tissues [9], we focussed particularly in this discussion on genes belonging to pathways clearly involved in oyster antiviral defense [28]. Several of the multigene families identified are potentially implicated in antiviral immunity. TRIM, one of the most represented multigene family in our sets of DEGs (one third), can target viral proteins for ubiquitination, in association with ubiquitin ligases (also identified here), to inhibit viral replication and induce RLR-STING and TLR-NF- $k B$ signaling pathways, which contribute to antiviral defense [29]. IFI44 multigene family are interferon-alfa inducible proteins, which are associated with infection of several viruses and can affect viral replication [30]. Some other genes like PARP could also participate to the defense against viral infection [31]. As TLR-NF-kB, JAK-STAT and RLR-STING pathways are 3 conserved pathways crucial to mount an efficient antiviral response [28], we made a particular focus on the DEGs belonging to these pathways. Only transcripts corresponding to one gene belonging to these pathways is overrepresented in the 3 resistant families. It corresponded to an endosomal Tolllike Receptor displaying similarities to the TLR 13, which can act as a sensor of viral and bacterial RNA in the TLR-NF- $k B$ signalling pathway [32,33]. This gene is particularly interesting because its sensor function could explain how these three resistant family may detect the viral infection earlier to mount a more rapid and efficient antiviral response, which is a common feature of these three resistant family [9]. Another gene, a tRNA adenosine deaminases (ADAT), displayed an overrepresentation of its transcripts in $\mathrm{R}_{\mathrm{F} 21}$ and $\mathrm{R}_{\mathrm{F} 23}$. $\mathrm{ADAT}$ (tRNA adenosine deaminases) gene is the ancestral form of ADAR (dsRNA-specific adenosine deaminase). ADAR has been recently described in $C$. gigas to be highly induced after OsHV-1 infection and potentially mediate editing (A to I) impacting RNAs expressed by OsHV-1 [34]. ADAT has also an I to A editase domain which could potentially edit OsHV-1 RNAs [34]. However, the anti- or pro-viral activity of this editing remains unknown in the case of OsHV-1 infection [34]. Considering their putative antiviral role, TLR 13 and ADAT represent good candidates whose function should be examined in future studies. In addition, a series of genes corresponding to the TLR-NF- $\mathrm{kB}$, JAK-STAT and RLRSTING pathways were differentially expressed only in one family. Overall, we obtained very different results for this set of DEGs between families produced from "mass selection" ( $\mathrm{R}_{\mathrm{F} 21}$ and $\mathrm{R}_{\mathrm{F} 23}$ ) and "natural selection" $\left(\mathrm{R}_{\mathrm{F} 48}\right)$ broodstocks. Indeed, most transcripts corresponding to these pathways were over-represented in the $R_{\mathrm{F} 48}$ family. They correspond to IRAK, NF-kB and TBK1 (TLR-NF-kB pathway), STAT and SOCS (JAK-STAT pathway) and IRFs and STING (RLR-STING pathway) genes. For the two selected families produced from "mass selection" ( $\mathrm{R}_{\mathrm{F} 21}$ and $\mathrm{R}_{\mathrm{F} 23}$ ), genes belonging to these molecular pathways were also identified. The majority of the corresponding transcripts were under- 
represented (2 TLRs, a MyD88, 2 TRAF, 2 STING, a 2', $5^{\prime}$-OAS and an IRF), while a minor part of them were over-represented (a TLR, 2 MyD88, and a SAMHD1). Thus, the molecular phenotype of the $R_{F 21}$ and $R_{F 23}$ families differs in part from that of the family $R_{F 48}$. $R_{F 21}$ and $\mathrm{R}_{\mathrm{F} 23}$ families are derived from a four-generation selection program conducted in natural environment showing a significant positive response to selection with a gain of resistance/survival that accumulated over the generations [16]. Consequently, the $\mathrm{R}_{\mathrm{F} 21}$ and $\mathrm{R}_{\mathrm{F} 23}$ families might develop mechanisms of resistance and a genetic architecture for this trait that are significantly different by comparison with the $\mathrm{R}_{\mathrm{F} 48}$ family whose genitors were confronted to a single POMS outbreak. We propose this rationale could explain the differences in the transcriptomic phenotype observed.

Interestingly, several DEGs commons and specifics to resistant oyster families have been previously associated to an early antiviral response of resistant oysters [15]. Among these DEGs, several genes related to antiviral signalling pathways (TLR-NF- $\mathrm{kB}$, JAK-STAT and RLRSTING pathways) are evidenced. Thus, both an overrepresentation at basal level and an up-regulation in early phase of infection of genes related to antiviral signalling pathways could confer resistance to POMS.

Overall, our results show that the selection process in these different oyster families has impacted their molecular phenotype in numerous molecular pathways, particularly for genes involved in functions related to antiviral immunity and maintenance of DNA integrity and repair. These modifications could participate in improving their fitness when confronted to a viral infection. Several identified DEGs were modulated in at least 2 disease resistant families, but most of them were differentially expressed in only a single family. Taken together, these results suggest that resistance mechanisms can vary at least partially among genotypes and that they are probably complex (multigenic). This is in agreement with a recent study of Gutierrez and collaborators [15], which suggested a polygenic nature of oyster resistance to OsHV-1.

\section{Conclusions}

A previous study demonstrated that POMS resistant oyster families present a more rapid antiviral response compared to susceptible oyster families [9]. This rapid antiviral response of resistant oysters blocks replication of the herpes virus OsHV-1 and prevents subsequent bacteraemia by opportunistic bacterial pathogens [9]. Here, we found differences in basal expression levels of genes related to immunity suggesting different immune status between resistant and susceptible oysters. These expression differences occurred for genes that mediate stress responses, protein modifications, maintenance of
DNA integrity and repair, and immune and antiviral pathways, including sensors. These differences could explain the early antiviral response, as well as the robustness of resistant oysters when confronted to POMS. Further studies will determine the function of these promising candidates and uncover the link between these expression differences and disease resistance. Such functional studies must precede identifying valuable candidates for future successful selective breeding.

\section{Methods}

\section{Production of biparental oyster families}

We collected wild stocks of Crassostrea gigas in farming as well as non-farming areas in two regions (French Mediterranean and Atlantic coasts) (Fig. 1). In addition, a fifth stock used selected oysters for their higher resistance to the infection by OsHV-1 [16]. From each stock, three bi-parental families were produced as previously described [9]. The 15 oyster families were maintained under controlled biosecured conditions at the Ifremer laboratory of Argenton (Brittany, France; lat 48.521536, long - 4.767799) to ascertain that no oyster pathogens would interfere with further experiments. The "pathogen-free" status of the animals was confirmed by i) the absence of OsHV-1 DNA detection by qPCR and ii) a low Vibrio presence ( $<10 \mathrm{cfu} / \mathrm{g}$ tissue) determined by isolation on selective culture medium (thiosulfate-citrate-bile salts-sucrose agar, TCBS) [7]. Oysters were observed to remain free of any abnormal mortality throughout the larvae until the beginning of the experimental and field infections. No mortality was observed during the two last months preceding the beginning of the experiments.

\section{Mesocosm infections}

The mesocosm infection protocol consists of cohabitation in controlled conditions between $C$. gigas oysters carrying the POMS disease ("donors") and "pathogenfree" C. gigas oysters ("recipients") [21]. A first experimental infection used donors previously exposed to the infectious environment of Atlantic origin. The donors were "pathogen-free" oysters (mixture of 116-day-old oysters from the 15 families, $17,700 \mathrm{~g}$ with a mean individual weight of $1.1 \mathrm{~g}$ ) were first deployed in a farming area (Logonna Daoulas, lat 48.335263, long - 4.317922) during the infectious period until the first mortalities occurred $(0.01 \%)$. This low percentage of mortality was sufficient to be certain that the oysters were diseased [7-9]. Then, donor oysters were transferred back to the laboratory and placed in contact with "pathogen-free" recipient oysters in a controlled environment (Fig. 2). The experiment was conducted using the same biomass $(1120 \mathrm{~g})$ of donors in cohabitation in 15 independent tanks (500 l), each containing one of the 15 families 
(recipient oysters with a mean individual weight of $1.1 \mathrm{~g}$ ) which were previously acclimatized in these structures for two weeks. The Atlantic experimental infection began on 17 July 2015 and ended on 31 July 2015. Similarly, a second experimental infection used donors previously exposed to the infectious environment of Mediterranean origin in a farming area (Thau lagoon, lat 43.418736, long 3.622620), except that donors deployed were a mixture of 176-day-old oysters from the 15 families $(26,500 \mathrm{~g}$ with a mean individual weight of $1.7 \mathrm{~g})$ and that the biomass of donors and the biomass of recipients in each tank was $1760 \mathrm{~g}$ each (recipient oysters with a mean individual weight of $1.73 \mathrm{~g}$ ). The Mediterranean experimental infection began on 21 September 2015 and ended on 6 October 2015.

\section{Field infections}

Concomitantly to the mesocosm infections, the survival rates of the 15 oysters families ( $n=100$ per family) were also recorded in oyster farms in the two infectious environments where were deployed the donors (Fig. 2, Logonna Daoulas in Atlantic area and Thau lagoon in Mediterranean area). The Atlantic field infection began on July 17th 2015 and ended on August 3rd 2015 while it was on September 21st 2015 and October 6th 2015 for the Mediterranean.

\section{Statistical analyses}

For Mesocosm and field infections, statistical data analysis was conducted in GraphPad Prism (V6.0) for Windows (GraphPad Software, La Jolla, USA). For all analysis, statistical significance was set at $p<0.05$. We performed non-parametric Kruskal-Wallis tests to compare mortalities. When Kruskal-Wallis tests were significant, we computed pairwise comparisons using MannWhitney U t-test.

\section{Oyster transcriptome analyses}

Before experimental infection, 10 oysters in triplicate were randomly sampled from each family without blinding protocols. The shell was removed, and pools of 10 oysters were flash frozen in liquid nitrogen. Oyster pools (10 individuals per pool) were ground in liquid nitrogen in 50-ml stainless steel bowls with 20-mm-diameter grinding balls (Retsch MM400 mill). The obtained powders (stored at $-80^{\circ} \mathrm{C}$ ) were then used for extracting RNA. RNA was extracted from powdered oysters using the Direct-Zol RNA Miniprep kit (Proteigene) according to the manufacturer's protocol. RNA concentration and purity were checked using a Qubit $^{\ominus}$ Fluorometer (Thermo Scientific), and their integrity was analysed by capillary electrophoresis on a BioAnalyzer 2100 (Agilent). RNA-seq library construction and sequencing were performed by the Bioenvironment platform (Perpignan,
France). PolyA + library preparation was performed from $500 \mathrm{ng}$ total RNA using NEBNext Ultra II Directional RNA Prep Kit for Illumina (New England Biolabs) according to manufacturer's instruction and sequenced on a NextSeq550 Instrument (SE $75 \mathrm{bp}$ ). All data treatments were carried out under a local galaxy instance [35]. Reads quality was checked using the Fastq-X toolkit [36] and since all reads display a Phred score above 26 over $90 \%$ of the their length no subsequent quality filtering was done. Adpator trimming was then performed using CutAdapt [37]. Paired-end mapping to the C. gigas reference genome (assembly version V9 [13]) was performed using RNAstar using default parameters (Galaxy Version 2.4.0d-2 [38]). The HTSeq-count was used to count the number of reads overlapping annotated genes. The parameters used were; mode $=$ Union, Stranded $=$ No, Minimum alignement quality $=10$, Feature type $=$ exon; ID attribute = gene_id; all other parameters used the default value (Galaxy Version v0.6.1) [39]. Finally, the differential gene expression levels were analysed with the DESeq2 R package [40]. Fold changes between each resistant and susceptible oysters were considered significant when the adjusted $p$-value (Padj) for multiple testing with the Benjamini-Hochberg procedure, which controls the false discovery rate (FDR), was $<0.05$.

Thus, each resistant family (6 replicates) was compared to each susceptible family (6 replicates) separately (RF21 vs. $\mathrm{S}_{\mathrm{F} 11}, \mathrm{R}_{\mathrm{F} 21}$ vs. $\mathrm{S}_{\mathrm{F} 14}, \mathrm{R}_{\mathrm{F} 21}$ vs. $\mathrm{S}_{\mathrm{F} 15} ; \mathrm{R}_{\mathrm{F} 23}$ vs. $\mathrm{S}_{\mathrm{F} 11}$, $\mathrm{R}_{\mathrm{F} 23}$ vs. $\mathrm{S}_{\mathrm{F} 14}, \mathrm{R}_{\mathrm{F} 23}$ vs. $\mathrm{S}_{\mathrm{F} 15} ; \mathrm{R}_{\mathrm{F} 48}$ vs. $\mathrm{S}_{\mathrm{F} 11}, \mathrm{R}_{\mathrm{F} 48}$ vs. $\mathrm{S}_{\mathrm{F} 14}$, $\mathrm{R}_{\mathrm{F} 48}$ vs. $\mathrm{S}_{\mathrm{F} 15}$ ). For each resistant family, only DEGs significant in the 3 comparisons and in the same way (upor down-represented for the three comparisons) were retained.

\section{Gene ontology annotation and enrichment analysis}

To work with current functional annotations of the $C$. gigas gene set, we performed a functional annotation (Additional file 6). Blastx comparison against the NR database was performed for the 28,027 genes annotated in the genome, with a maximum number of target hits of 20 and a minimum e-value of 0.001 . From these 20 hits, a percentage of mean similarity was calculated and we retained only results with mean similarity $>40 \%$. XML blast result files were loaded onto Blast2GO [41] for GO mapping and annotation with the b2g_sep13 version of the B2G database. These results were used as inputs for GO enrichment analysis, which was performed using adaptive clustering and a rank-based statistical test (Mann-Whitney U-test combined with adaptive clustering). The $\mathrm{R}$ and Perl scripts used [42] can be downloaded [https://github.com/z0on/GO_MWU]. The following parameters were used for adaptive clustering: largest $=0.5 ; \quad$ smallest $=5$; clusterCutHeight $=0.25$. For the continuous value characterization of each gene in 
the dataset, we used a strategy aiming to take into account both the level of expression and the significance of the differential expression. To combine these two factors, the $\log 2$ fold change was attributed to genes that were significantly differentially expressed (adjusted $p<$ $0.05)$, while a zero was attributed to the others. A category was considered enriched with a FDR $<1 \%$.

\section{DNA extraction and quantification of OsHV-1 and total Vibrio}

DNA extractions were performed from the same samples used for RNA extraction using the Nucleospin tissue kit (Macherey-Nagel) according to the manufacturer's protocol. In order to improve DNA extractions, we added a crushing step, which consisted in an additional $12 \mathrm{~min}$ mechanical lysis using zirconium beads $(0.1 \mathrm{~mm}$ dia., BioSpec) before the 90 min enzymatic lysis in the presence of proteinase $\mathrm{K}$. DNA concentration and purity were checked with NanoDrop One (Thermo Scientific). Quantification of OsHV-1 and total Vibrio $16 \mathrm{~S}$ rDNA was performed using quantitative PCR (qPCR). All amplification reactions were performed using a Roche LightCycler 480 Real-Time thermocycler (qPHD-Montpellier GenomiX platform, Montpellier University, France). A Labcyte Acoustic Automated Liquid Handling Platform (ECHO) was used for pipetting into the 384-well plate (Roche). The total qPCR reaction volume was $1.5 \mu \mathrm{l}$ with $0.5 \mu \mathrm{l}$ DNA (40 $\mathrm{ng}^{-1} \mathrm{l}^{-1}$ ) and $1 \mu \mathrm{l}$ LightCycler 480 SYBR Green I Master mix (Roche) containing $0.5 \mu \mathrm{M}$ PCR primer (Eurogenetec SA). Virus-specific primer pairs targeted a DNA polymerase catalytic subunit (DP, ORF100, AY509253): Fw-ATTGATGATGTGGATAATCTGTG and RevGGTAAATACCATTGGTCTTGTTCC [43]. Total Vibrio specific primer pairs were Fw-GGCGTAAAGCGCAT GCAGGT and Rev-GAAATTCTACCCCCCTCTACAG [44]. qPCR reactions were performed with the following program: $95^{\circ} \mathrm{C}$ for $10 \mathrm{~min}$, followed by 40 cycles of denaturation at $95^{\circ} \mathrm{C}$ for $10 \mathrm{~s}$, hybridization at $60^{\circ} \mathrm{C}$ for $20 \mathrm{~s}$ ) and elongation at $72{ }^{\circ} \mathrm{C}$ for $25 \mathrm{~s}$ ). After these PCR cycles a melting temperature curve of the amplicon was generated to verify the specificity of the amplification. Absolute quantification of OsHV-1 and total Vibrio 16S rDNA copies were calculated by comparing the observed $\mathrm{Cq}$ values to a standard curve generated from the DNA polymerase catalytic subunit or from the 16S rDNA of Vibrio tasmaniensis LGP32 amplification products cloned into the pCR4-TOPO vector.

\section{Supplementary information}

Supplementary information accompanies this paper at https://doi.org/10. 1186/s12864-020-6471-x.

Additional file 1. OsHV-1 and total vibrio colonization in oysters during the two mesocosm experiments. OsHV-1 and total vibrio quantifications in mesocosm experiments from infectious environments of Atlantic or
Mediterranean origins at the beginning of the experiments (TO h) and before the first mortalities (T72 h) in susceptible (S: $\left.S_{F 11}, S_{F 14}, S_{F 15}\right)$ and resistant (R: $R_{F 21}, R_{F 23}, R_{F 48}$ ) oyster families. (A) The OsHV-1 load was quantified by qPCR and expressed as viral genomic units per ng of oyster DNA. (B) The total 165 vibrio load was quantified by $\mathrm{QPCR}$ and expressed as $16 \mathrm{~S}$ copy number per ng of oyster DNA. Dots represent distinct pools of 10 oysters and bars represent the mean \pm SD.

Additional file 2. List of DEGs shared by at least two resistant families. This table presents the Log2 fold change of each CGI differentially expressed (significant) in the three resistant oyster families $\left(R_{F 21}, R_{F 23}\right.$ and $R_{F 48}$ ) compared to the three susceptible families $\left(S_{F 11}, S_{F 14}\right.$ and $\left.S_{F 15}\right)$, the Blast results, the enriched functional categories and details of each comparison (Log2 fold change, $p$-value and number of reads).

Additional file 3. List of DEGs specifics to the $R_{F 21}$ oyster family. This table presents the Log2 fold change of each CGI differentially expressed (significant) only in the the $R_{\mathrm{F} 21}$ oyster family compared to the three susceptible families $\left(\mathrm{S}_{\mathrm{F} 11}, \mathrm{~S}_{\mathrm{F} 14}\right.$ and $\left.\mathrm{S}_{\mathrm{F} 15}\right)$, the Blast results, the enriched functional categories and details of each comparison (Log2 fold change, p-value, GO categories and number of reads).

Additional file 4. List of DEGs specifics to the $R_{F 23}$ oyster family. This table presents the Log2 fold change of each CGl differentially expressed (significant) only in the the $R_{F 23}$ oyster family compared to the three susceptible families $\left(\mathrm{S}_{\mathrm{F} 11}, \mathrm{~S}_{\mathrm{F} 14}\right.$ and $\left.\mathrm{S}_{\mathrm{F} 15}\right)$, the Blast results, the enriched functional categories and details of each comparison (Log2 fold change, p-value, GO categories and number of reads).

Additional file 5. List of DEGs specifics to the R $\mathrm{F}_{488}$ oyster family. This table presents the Log2 fold change of each CGI differentially expressed (significant) only in the the $R_{F 48}$ oyster family compared to the three susceptible families $\left(S_{F 11}, S_{F 14}\right.$ and $\left.S_{F 15}\right)$, the Blast results, the enriched functional categories and details of each comparison (Log2 fold change, p-value, GO categories and number of reads).

Additional file 6 Blast $2 \mathrm{GO}$ annotation of the 28,027 genes identified in the genome of $C$. gigas.

\section{Abbreviations}

2',5'-OAS: 2',5'- oligoadenylate synthase; ADAR: dsRNA-specific adenosine deaminase; ADAT: tRNA adenosine deaminases; CGI: Crassostrea gigas identifier; DEGs: Differentially expressed genes; HSP: Heat shock proteins; IFI44: Interferon Induced Protein 44; IRAK: Interleukin-1 receptor-associated kinase; IRF: Interferon regulatory factor; JAK: Signal transducers and activators of transcription; MyD88: Myeloid differentiation primary response 88; NFkB: Nuclear Factor Kappa B; PARP: Poly [ADP-ribose] polymerases; POMS: Pacific oyster mortality syndrome; QTL: Quantitative trait loci; RIGI: Retinoic acid-inducible gene I; RLR: RIG-I-like receptors;

SAMHD1: Deoxynucleoside triphosphate triphosphohydrolase;

SOCS: Suppressors of cytokine signaling; SR: Scavenger receptors;

STAT: Signal transducer and transcription activator; STING: Stimulator of interferon genes; TBK1: Serine/Threonine-Protein Kinase; TLR: Toll-like receptor; TNF: Tumor Necrosis Factor; TRAF: TNF receptor-associated factor; TRIM: Tripartite Motif containing proteins

\section{Acknowledgements}

We warmly thank the staff of the Ifremer site of Argenton (LPI, PFOM) and Sète (LER), and the Comité Régional de Conchyliculture de Méditerranée (CRCM) for technical support in the collection of the oyster genitors and reproduction. We also thank Vangeli Geshkovski, Maxime Lafont, Eve Toulza and Delphine Destoumieux-Garzón for technical support or fruitful discussions and the Bio-Environnement platform of the University Perpignan Via Domitia for support in NGS library preparation and sequencing. The authors are grateful also to Philippe Clair from the qPHD platform/Montpellier genomix for RNA quality control and useful advice. This work, through the use of the GENSEQ platform (http://www.labex-cemeb.org/fr/genomique-environnementale-2) from the labEx CeMEB, benefited from the support of the National Research Agency under the "Investissements d'avenir" program (reference ANR-10-LABX-04-01). We also thank the "Bio-Environnement" technological UPVD platform (Région Occitanie, CPER 2007-2013 Tecnoviv, CPER 2015-2020 Bioenvironnement) for access to the sequencing platform. This study is set within the framework of the "Laboratoires d'Excellence 
(LABEX)" TULIP (ANR-10-LABX-41). We thank Life Science Editors for editorial assistance.

\section{Authors' contributions}

$J D L, A L, B P, C M, V P, L D, C M, J M E, P H, F L, M L, Y G$ and $G M$ performed oyster experiments. JDL, AL, VP, PLS, CM, JVD, JFA, YG and GM performed RNA-sec analyses. JDL, BP and GM designed experiments. JDL, BP, YG and GM interpreted results. JDL, YG and GM wrote the paper. All the authors have revised and approved the manuscript submission.

\section{Funding}

The present study was supported by the ANR project DECIPHER (ANR-14CE19-0023), by the ANR project DECICOMP and by Ifremer, CNRS, Université de Montpellier and Université de Perpignan via Domitia.

\section{Availability of data and materials}

RNA-seg data have been made available through the SRA database (BioProject accession number PRJNA423079 with submission ID from SRR10799809 to SRR10799844). Complementary information is available from the corresponding authors on reasonable request.

\section{Ethics approval and consent to participate}

All the experiments were conducted according to the ethics committee of Ifremer. Oyster genitors were sampling in field and sites for sampling were accessible on foot or by boat. No permit was required to harvest oysters. A very small fraction of the oysters $(<0.1 \%$ in every site) was collected without disturbance. Except for the production of biparental families of oysters, the study did not used samples collected from the field.

\section{Consent for publication}

The manuscript has been seen and approved by all of the authors.

\section{Competing interests}

The authors declare that they have no competing interests.

\section{Author details}

${ }^{1}$ IHPE, Université de Montpellier, CNRS, Ifremer, Université de Perpignan Via Domitia, Place E. Bataillon, CC080, 34095 Montpellier, France. ${ }^{2}$ Ifremer, LEMAR UMR 6539, UBO/CNRS/IRD/Ifremer, 11 presqu'île du vivier, 29840 Argenton-en-Landunvez, France. ${ }^{3}$ Ifremer, UMR 241 Écosystèmes Insulaires Océaniens, Labex Corail, Centre Ifremer du Pacifique, BP 49, 98725 Tahiti, French Polynesia. ${ }^{4}$ Ifremer, Laboratoire de Génétique et Pathologie des Mollusques Marins, Avenue du Mus de Loup, 17930 La Tremblade, France. ${ }^{5}$ MARBEC, Université de Montpellier, CNRS, IRD, Ifremer, 87 Avenue Jean Monnet, 34200 Sète, France.

\section{Received: 17 October 2019 Accepted: 8 January 2020}

\section{Published online: 20 January 2020}

\section{References}

1. FAO: Cultured Aquatic Species Information Programme. Crassostrea gigas. Cultured Aquatic Species Information Programme. . In.: FAO Fisheries and Aquaculture Department.; 2016: http://www.fao.org/fishery/culturedspecies/ Crassostrea gigas/en.

2. EFSA: P. O. A. H. W. Oyster mortality. EFSA Journal 2015, 13( 4122-n/a).

3. Paul-Pont I, Dhand NK, Whittington RJ. Influence of husbandry practices on OsHV-1 associated mortality of Pacific oysters Crassostrea gigas. Aquaculture. 2013:412:202-14.

4. Azéma P, Lamy JB, Boudry P, Renault T, Travers MA, Dégremont L. Genetic parameters of resistance to Vibrio aestuarianus, and OsHV-1 infections in the Pacific oyster, Crassostrea gigas, at three different life stages. Genet Sel Evol. 2017:49:1-16.

5. Le Roux F, Wegner KM, Polz MF. Oysters and Vibrios as a model for disease dynamics in wild animals. Trends Microbiol. 2016;24(7):568-80.

6. Pernet F, Barret J, Le Gall P, Corporeau C, Dégremont L, Lagarde F, Pépin JF, Keck N. Mass mortalities of Pacific oysters Crassostrea gigas reflect infectious diseases and vary with farming practices in the Mediterranean Thau lagoon, France. Aquaculture Environ Interact. 2012;2(3):215-37.

7. Petton B, Bruto M, James A, Labreuche $Y$, Alunno-Bruscia M, Le Roux F. Crassostrea gigas mortality in France: the usual suspect, a herpes virus, may not be the killer in this polymicrobial opportunistic disease. Front Microbiol. 2015;6:686.

8. Petton B, Pernet F, Robert R, Boudry P. Temperature influence on pathogen transmission and subsequent mortalities in juvenile Pacific oysters Crassostrea gigas. Aquaculture Environ Interact. 2013;3(3):257-73.

9. de Lorgeril J, Lucasson A, Petton B, Toulza E, Montagnani C, Clerissi C, VidalDupiol J, Chaparro C, Galinier R, Escoubas JM, et al. Immune-suppression by OsHV-1 viral infection causes fatal bacteraemia in Pacific oysters. Nat Commun. 2018;9(1):4215.

10. Rubio T, Oyanedel D, Labreuche Y, Toulza E, Luo X, Bruto M, Chaparro C, Torres M, de Lorgeril J, Haffner $P$, et al. Species-specific mechanisms of cytotoxicity toward immune cells determine the successful outcome of Vibrio infections. Proc Natl Acad Sci U S A. 2019:116(28):14238-47.

11. Camara MD, Yen S, Kaspar HF, Kesarcodi-Watson A, King N, Jeffs AG, Tremblay LA. Assessment of heat shock and laboratory virus challenges to selectively breed for ostreid herpesvirus 1 (OsHV-1) resistance in the Pacific oyster, Crassostrea gigas. Aquaculture. 2017:469:50-8.

12. Degremont L, Lamy JB, Pepin JF, Travers MA, Renault T. New insight for the genetic evaluation of resistance to Ostreid Herpesvirus infection, a worldwide disease, in Crassostrea gigas. PLoS One. 2015;10(6):e0127917.

13. Zhang G, Fang X, Guo X, Li L, Luo R, Xu F, Yang P, Zhang L, Wang X, Qi H, et al. The oyster genome reveals stress adaptation and complexity of shell formation. Nature. 2012;490(7418):49-54.

14. Gutierrez AP, Turner F, Gharbi K, Talbot R, Lowe NR, Penaloza C, McCullough M, Prodohl PA, Bean TP, Houston RD. Development of a Medium Density Combined-Species SNP Array for Pacific and European Oysters (Crassostrea gigas and Ostrea edulis). G3 (Bethesda). 2017;7(7):2209-18.

15. Gutierrez AP, Bean TP, Hooper C, Stenton CA, Sanders MB, Paley RK, Rastas P, Bryrom M, Matika O, Houston RD. A Genome-Wide Association Study for Host Resistance to Ostreid Herpesvirus in Pacific Oysters (Crassostrea gigas). G3 (Bethesda). 2018;8(4):1273-80.

16. Dégremont L, Nourry M, Maurouard E. Mass selection for survival and resistance to OsHV-1 infection in Crassostrea gigas spat in field conditions: response to selection after four generations. Aquaculture. 2015:446:111-21.

17. Ballester AR, Norelli J, Burchard E, Abdelfattah A, Levin E, Gonzalez-Candelas L, Droby S, Wisniewski M. Transcriptomic response of resistant (PI613981Malus sieversii) and susceptible ("Royal Gala") genotypes of apple to blue Mold (Penicillium expansum) infection. Front Plant Sci. 2017:8:1981.

18. Kim KH, Kang YJ, Kim DH, Yoon MY, Moon JK, Kim MY, Van K, Lee SH. RNASeq analysis of a soybean near-isogenic line carrying bacterial leaf pustuleresistant and -susceptible alleles. DNA Res. 2011;18(6):483-97.

19. Sun J, Cao L, Li H, Wang G, Wang S, Li F, Zou X, Wang J. Early responses given distinct tactics to infection of Peronophythora litchii in susceptible and resistant litchi cultivar. Sci Rep. 2019;9(1):2810.

20. Burioli EAV, Prearo M, Riina MV, Bona MC, Fioravanti ML, Arcangeli G, Houssin M. Ostreid herpesvirus type 1 genomic diversity in wild populations of Pacific oyster Crassostrea gigas from Italian coasts. J Invertebr Pathol. 2016;137:71-83.

21. Petton B, Boudry P, Alunno-Bruscia M, Pernet F. Factors influencing diseaseinduced mortality of Pacific oysters Crassostrea gigas. Aquaculture Environ Interact. 2015;6(3):205-22.

22. Dégremont L. Evidence of herpesvirus (OsHV-1) resistance in juvenile Crassostrea gigas selected for high resistance to the summer mortality phenomenon. Aquaculture. 2011:317(1-4):94-8.

23. Dégremont L, Bédier E, Boudry P. Summer mortality of hatchery-produced Pacific oyster spat (Crassostrea gigas). II. Response to selection for survival and its influence on growth and yield. Aquaculture. 2010;299(1-4):21-9.

24. Pernet F, Lagarde F, Le Gall P, D'Orbcastel ER. Associations between farming practices and disease mortality of Pacific oyster Crassostrea gigas in a Mediterranean lagoon. Aquaculture Environ Interact. 2014:5:99-106.

25. Nédélec Y, Sanz J, Baharian G, Szpiech ZA, Pacis A, Dumaine A, Grenier J-C, Freiman A, Sams AJ, Hebert S, et al. Genetic Ancestry and Natural Selection Drive Population Differences in Immune Responses to Pathogens. Cell. 2016;167(3):657-669.e621.

26. Sanz J, Randolph HE, Barreiro LB. Genetic and evolutionary determinants of human population variation in immune responses. Curr Opin Genet Dev. 2018:53:28-35.

27. Cosseau C, Wolkenhauer O, Padalino G, Geyer KK, Hoffmann KF, Grunau C. (Epi) Genetic inheritance in Schistosoma mansoni: a systems approach. Trends Parasitol. 2017:33(4):285-94.

28. Green TJ, Raftos D, Speck P, Montagnani C. Antiviral immunity in marine molluscs. J Gen Virol. 2015;96(9):2471-82. 
29. Wei Y, Chen S, Wang M, Cheng A. Tripartite motif-containing proteins precisely and positively affect host antiviral immune response. Scand Immunol. 2018;87(6):e12669.

30. Power D, Santoso N, Dieringer M, Yu J, Huang H, Simpson S, Seth I, Miao H, Zhu J. IFI44 suppresses HIV-1 LTR promoter activity and facilitates its latency. Virology. 2015;481:142-50.

31. Daugherty MD, Young JM, Kerns JA, Malik HS. Rapid evolution of PARP genes suggests a broad role for ADP-ribosylation in host-virus conflicts. PLoS Genet. 2014;10(5):e1004403.

32. Oldenburg M, Kruger A, Ferstl R, Kaufmann A, Nees G, Sigmund A, Bathke B, Lauterbach H, Suter M, Dreher S, et al. TLR13 recognizes bacterial $23 \mathrm{~S}$ rRNA devoid of erythromycin resistance-forming modification. Science. 2012; 337(6098):1111-5.

33. Shi Z, Cai Z, Sanchez A, Zhang T, Wen S, Wang J, Yang J, Fu S, Zhang D. A novel toll-like receptor that recognizes vesicular stomatitis virus. J Biol Chem. 2011;286(6):4517-24.

34. Rosani U, Bai CM, Maso L, Shapiro M, Abbadi M, Domeneghetti S, Wang CM, Cendron L, MacCarthy T, Venier P. A-to-l editing of Malacoherpesviridae RNAs supports the antiviral role of ADAR1 in mollusks. BMC Evol Biol. 2019; 19(1):149.

35. Goecks J, Nekrutenko A, Taylor J. Galaxy: a comprehensive approach for supporting accessible, reproducible, and transparent computational research in the life sciences. Genome Biol. 2010;11(8):R86.

36. Blankenberg D, Gordon A, Von Kuster G, Coraor N, Taylor J, Nekrutenko A, Galaxy T. Manipulation of FASTQ data with Galaxy. Bioinformatics. 2010; 26(14):1783-5.

37. Martin M. Cutadapt removes adapter sequences from high-throughput sequencing reads. EMBnetJournal. 2011;17:10-12.

38. Dobin A, Davis CA, Schlesinger F, Drenkow J, Zaleski C, Jha S, Batut P, Chaisson M, Gingeras TR. STAR: ultrafast universal RNA-seq aligner. Bioinformatics. 2013;29(1):15-21.

39. Anders S, Pyl PT, Huber W. HTSeq--a Python framework to work with highthroughput sequencing data. Bioinformatics. 2015;31(2):166-9.

40. Love Ml, Huber W, Anders S. Moderated estimation of fold change and dispersion for RNA-seq data with DESeq2. Genome Biol. 2014:15(12):550.

41. Conesa A, Gotz S, Garcia-Gomez JM, Terol J, Talon M, Robles M. Blast2GO: a universal tool for annotation, visualization and analysis in functional genomics research. Bioinformatics. 2005;21(18):3674-6.

42. Wright RM, Aglyamova GV, Meyer E, Matz MV. Gene expression associated with white syndromes in a reef building coral, Acropora hyacinthus. BMC Genomics. 2015;16:371.

43. Davison AJ, Trus BL, Cheng N, Steven AC, Watson MS, Cunningham C, Le Deuff RM, Renault T. A novel class of herpesvirus with bivalve hosts. J Gen Virol. 2005;86(Pt 1):41-53.

44. Mansergh S, Zehr JP. Vibrio diversity and dynamics in the Monterey Bay upwelling region. Front Microbiol. 2014;5:48,

\section{Publisher's Note}

Springer Nature remains neutral with regard to jurisdictional claims in published maps and institutional affiliations.

Ready to submit your research? Choose BMC and benefit from:

- fast, convenient online submission

- thorough peer review by experienced researchers in your field

- rapid publication on acceptance

- support for research data, including large and complex data types

- gold Open Access which fosters wider collaboration and increased citations

- maximum visibility for your research: over $100 \mathrm{M}$ website views per year

At $\mathrm{BMC}$, research is always in progress.

Learn more biomedcentral.com/submissions 